\title{
Energy Production from Steam Gasification Processes and Parameters that Contemplate in Biomass Gasifier- A review
}

\author{
Samarjeet Singh Siwal $^{\mathrm{a}}$, Qibo Zhang ${ }^{\text {a,b }}{ }^{*}$, Changbin Sun ${ }^{\mathrm{a}}$, Sourbh Thakur,d, Vijai \\ Kumar Gupta ${ }^{\mathrm{e}}$ and Vijay Kumar Thakur,g
}

a Key Laboratory of Ionic Liquids Metallurgy, Faculty of Metallurgical and Energy Engineering, Kunming University of Science and Technology, Kunming, 650093, P.R. China

${ }^{\mathrm{b}}$ State Key Laboratory of Complex Nonferrous Metal Resources Cleaning Utilization in Yunnan Province, Kunming 650093, P.R. China

${ }^{\mathrm{c} C e n t e r}$ for Computational Materials Science, Institute of Physics, Slovak Academy of Sciences, 84511 Bratislava, Slovakia

${ }^{\mathrm{d}}$ School of Chemistry, Shoolini University, Solan 173212, Himachal Pradesh, India

eDepartment of Chemistry and Biotechnology, ERA Chair of Green Chemistry, Tallinn University of Technology, 12618 Tallinn, Estonia

${ }^{\mathrm{f} E n h a n c e d ~ C o m p o s i t e s ~ a n d ~ S t r u c t u r e s ~ C e n t e r, ~ S c h o o l ~ o f ~ A e r o s p a c e, ~ T r a n s p o r t ~ a n d ~}$ Manufacturing, Cranfield University, Bedfordshire MK43 0AL, UK

${ }^{g}$ Department of Mechanical Engineering, School of Engineering, Shiv Nadar University, Uttar Pradesh 201314, India

*Corresponding author: qibozhang@ @ust.edu.cn; 


\begin{abstract}
The transformation of biomass using steam gasification is a chemical route to facilitate changes in organic or residue supported carbonaceous substances addicted to carbon mono-oxide, hydrogen including carbon-di-oxide, etc. However, to commercialize the method of steam gasification, the hurdles persist during the gasification as well as downstream processing. This article delivers a summary of the different approaches that are described in the previous studies to achieve $\mathrm{H}_{2}$ refinement and adaptation within the gasifier system. These include advanced aspects in the research and development of biomass gasification (alike advancements under the gasification operation). The upshot of diverse operating conditions like steam flow rate, operating temperature, moisture content, gasifier agents, residence time, biomass to air, steam to biomass, equivalence ratio, etc. towards the execution of biomass gasifier. This review accomplishes that the interdependence of several issues must be considered in point to optimise the producer gas.
\end{abstract}

Keywords: Energy; Steam gasification; biomass; hydrogen production; gasifier system. 


\section{Introduction}

Currently, there are numerous ways and technologies available around us to store, renovate or amplify the energy. Various types of energy can be branded into two major forms: finite resources (e.g. coal (Song et al., 2019), petroleum (Wei et al., 2017), uranium (Tendall \& Binder, 2011) and natural gas (Navakas et al., 2018), etc.) and renewable resources (such as solar (Li et al., 2017), wind (Bechtle et al., 2019), bioenergy (Amoah et al., 2019), tidal (Loisel et al., 2018), and ocean thermal energy (Zhang et al., 2019a). Bioenergy is the renewable form of energy, as every new crop either harvest is an incomplete regeneration of its reserve base that itself is directed to deficiency due it is to accept being fuel. This is a generic phrase for substance obtained from flowering plants or from pet dung (which is efficiently a prepared kind of plant matter) (Chuayboon et al., 2018; La Villetta et al., 2017). In other words, any organic substance which has stored sunshine during the appearance of chemical power can be termed as biomass. Biomass is obtained from existing organisms, for example, plants and pets which is presently living or was a slight generation before (Susastriawan et al., 2017). Fossil feedstock cannot be regenerated while biomass exhibits this unique capability, as well as, on behalf of that purpose biomass is supposed natural (Singha \& Thakur, 2009; Thakur et al., 2012). That is an example of the essential affinities for biomass being a root of potential or compounds (Fortunato et al., 2017). Biomass can also be separated within two general factions: (1) Virgin biomass is recovered from timber, shrubs, leaflets (lignocellulose), products including vegetables (carbohydrates), and (2) Decay biomass comprises solid plus fluid exhaustion, human and animal garbage, residue, vapours originated by land-filling (primarily methane) furthermore agricultural scraps (Wang et al., 2017a). 
The transformation technologies in favour of consuming biomass can be divided into three major groups: direct combustion routes, thermochemical routes and biochemical routes. Straight oxidization trades mainly beside fundamental combustibles, for example, the order in which it is possible or subsequent any dealing (dry, size, briquette, etc.). In the two new methods, the first combustible is turned towarsd a following combustible (solid, gas and liquid kind) through methods, for example, pyrolysis, gasification carbonization, absorption, evaporation, etc. The second combustibles received from the resolution method may be applied straight towards several end-use enterprises for additional dealing (de Sales et al., 2017). The direct combustion of biomass materials commonly occurs in smog, including ash contamination except proper filtering apparatus is employed (Masmoudi et al., 2017). Biochemical methods execute the application about the biochemistry of the fresh substances, and the progress of microbial bodies to provide volatile and fluid combustibles like biogas, ethanol, and methanol. Anaerobic reactors are employed for the generation of biogas from dung and harvest residuals. Fermentation is another example of a biochemical process in which micro-bodies (natural fungus) crackdown sugars to produce ethanol. Ethanol which is originated from specific biomass elements that include sugars, carbohydrate or cellulose is considered being a vital potential substitute root of fluid fuels for the transportation area. Ethanol blended with conventional fuel like petrol or diesel is widely used nowadays (Manochio et al., 2017). Although fermentation is successfully used to produce ethanol, it is feedstock limited, time-consuming and low yield process.

In thermochemical transformation, the total biomass is converted into gases or liquids fuels or reliable charcoal, which are then used as precursors to synthesize useful chemicals or are used straight (Basu, 2010). The invention of thermal power is the primary driver in support of this renovation route that has four full paths: (1) Combustion, (2) Pyrolysis, (3) 
Liquefaction, as well as (4) Gasification. Combustion is a specific chain concerning exothermic effects within the fuel, and an oxidant is also followed through the creation of heat plus renovation about chemical sorts. A striking benefit of gasification related to pyrolysis is the higher versatility to simultaneously valorize plastics of various configuration or compounds or plastics combined with different raw materials. The arrangement, and consequently purposes of the gas generated persevere the gasifying agent applied. Therefore, air gasification of scrap plastics guides to synthetic gas by a medium heating value within the 6-8 $\mathrm{MJ} \mathrm{m}^{-3}$ scale, including its principal concern being energy generation. Although, steam gasification provides for manufacturing an $\mathrm{N}_{2}$ available synthetic gas including a heating value higher $15 \mathrm{MJ} \mathrm{m}^{-3}$, among its structure being fit for synthesis purposes (Lopez et al., 2018).

There is an enormous potential towards achieving the renewable power of biomass and different kinds of bio-waste. Steam gasification holds the path within valuable power that may be collected from consumption. This review is a signal in the area for focused investigation shortly. The goals of the study are: (i) to give the continuous advancement in the domain of laboratory and analytical characters connected by steam gasification; and (ii) to deliver the existing situation of the investigation in this area of steam gasification of several biomasses including the current study holes. The principal fields comprised in the survey involve gasification; steam gasification; experimental studies on steam gasification using various types of gasifiers and comparison of operating conditions (Murugan \& Joseph Sekhar, 2017). The outline of this review article can be summarized as follows:

\section{History and different zones of steam gasification of biomass}


Gasification was invented individually in together France and England during 1798. Since 1850, the expertise has been improved near the duration, which was conceivable to light enough of London, including the produced gas or "town gas" of coal (Singer, 1958). During World War, I and II wood gas generators, called Gasogene, were used when fuel supply was not enough but after a few years, a more reliable and cheap technology was developed that runs on petroleum; and gradually the use of gas produced by biomass was reduced. Due to the energy crisis in most of the countries and towering cost of petroleum, the biomass-based gasification process is again in focus in the recent past (T. Reed, 1988). The gasification of biomass is one of the majorly used procedures to increase the competence of energy harnessing from biomass. Gasification is a method that takes carbonaceous resources like its feed, for example, coal, petroleum, either biomass and converts within carbon monoxide as well as hydrogen. This feedstock reacts through a prohibited oxygen volume and/or steam at high temperatures (T. Reed, 1988). It is also a pretty effective technique for obtaining energy by various kinds of organic elements, including the ability to being used as a complete waste clearance procedure.

Moreover, the usage of producer gas is possibly useful in comparison to straight combustion like the primary fuel because this can be combusted on soaring temperatures. The typical composition of hydrogen in producer gas varies from $5-25 \%$ depending upon the fuel's moisture content. After separation and purification, it can be utilized in a fuel cell, and the biomass gasification process can be considered as one of the prominent processes for biohydrogen production (Ali et al., 2017). There are mainly two techniques available for gasification of biomass, viz., fixed bed mode and fluidized bed mode (Bhave, 2001). The three most essential configurations of fixed bed gasifiers include Updraft, Downdraft, and Cross draft mode of operations (Bridgwater, 2002). Merits and demerits of different types of 
gasification reactors are described in table 1. Irrespective of gasifier configuration, the gasification process may be separated within four different sections: drying/preheating, pyrolysis/devolatilization, combustion as well as reduction/gasification region. This description of these four zones within the subsequent segments (Richardson et al., 2015). Fed biomass is dehydrated inside the top segment. The dried biomass flows earthward towards the upper-middle region, allowing the pyrolysis as well as the tar transformation reactions to happen. The unconverted tars alonwith the gases subsequqntly grow to the oxidation region, where combustion takes place at $1000-1400^{\circ} \mathrm{C}$. The as-formed chemical sorts lastly pass over a reduction region where the $\mathrm{H}_{2}$ and $\mathrm{CO}$ contents are improved. The generated gas comprises a flat quantity of particulates and tars $\left(\sim 1 \mathrm{~g} / \mathrm{Nm}^{3}\right)$ because most utmost of the tars is combusted during the oxidation region. The downdraft reactor is especially great accommodated during a clean synthetic gas including a low content of tar and particulates is needed.

\subsection{Drying/Preheating zone}

The first zone in which the feed comes in contact with the biomass gasifier is the drying zone. Drying is a mass transfer operation ensuing within the elimination of water humidity through vanishing as of a solid or semi-solid. There must be a resource of heat to accomplish this and to a sink of the vapour consequently produced. This process should preferably take place at a temperature of around $160^{\circ} \mathrm{C}$ via ravage heat from the conversion procedure. During each drying region, feed descends within that gasifier (also moisture) is eliminated applying the heat produced inside the regions following through dissipation. The water vapour flows downward in the gasifier. Part of it may be reduced to hydrogen in the reduction zone and the break will finish up while moisture within the gas. The speed of drying pivot on the exterior section concerning the fuel, the temperature variation among the 7 
supplies and the warm gases, the re-circulation swiftness, comparative moisture of certain gases, furthermore the intrinsic diffusivity of precipitation in the fuel (Dogru et al., 2002). In this zone, no chemical reaction takes place, and only the water removal is carried out.

\subsection{Pyrolysis/Devolatilization zone}

The devolatilization concerning biomass is a promising path towards the generation of compact (charcoal), fluid (tar and additional organics for example acetic acid, acetone also methanol) including volatile outcomes $\left(\mathrm{H}_{2}, \mathrm{CO}_{2}, \mathrm{CO}\right)$. Individual results are of importance, while others are a potential substitute for origins like power. It is a method through which a biomass raw material thermally demoted during the inadequacy of oxygen/air. The fundamental aspects which need vacancy while pyrolysis is heat removal from a heat origin, heading towards an improvement inside temperature in the combustible and introduction of pyrolysis effects owing to the raised temperature, driving over the liberation of gaseous also the development of char. Additionally, the outflow of volatiles, appearing in heat transfer between the hot gaseous including unpyrolysed fuel.

Furthermore, condensation of any of the volatiles under the chillier bits regarding the fuel to produce tar also autocatalytic subsequent pyrolysis reactions owing to specific synergies (Arregi et al., 2018; Guedes et al., 2018; Rony et al., 2018; Sun et al., 2018). A self-governing pyrolysis method can also be used during the generation of valuable fuels or substances. The whole rule of pyrolysis can be divided within the main and subsequent steps. During this process, a small bit of biomass is fired in an inactive environment. Heat is fundamentally shifted towards the shred exterior through emission so, the temperature within this bit raises; the reason behind it may be the elimination of condensation which is already inside the biomass bit and the pyrolysis responses to happen. The heat variations are owing to 
the chemical effect's switches supply in the direction of a heat slope being the role of the moment that is fragmentary. Fumes outcomes pass within the holes of the scrap and engage in the heat transferal method. The pyrolysis responses continue including a rate relying on the economic temperature. While in the pyrolysis method, the openings regarding the compact are grown; also, the compact bit slightly fits further penetrable that of the biomass follows in fumes (Curtis \& Miller, 1988).

\subsection{Combustion zone}

In the combustion zone or oxidation, biomass along with the unstable goods of pyrolysis are oxidized ensuing within a rapid rise during temperature equipped $1200{ }^{\circ} \mathrm{C}$ due to highly exothermic reactions. The oxidation reactions regarding gaseous state happen quite rapidly and furthermore, the oxygen is absorbed that can be dispersed on the exterior at the char. Hence, no flaming of compact char can get a position. Oxidation like the condensable organic section to develop under atomic weight outputs is essential in decreasing the quantity of tar generated through a gasifier (Dogru et al., 2002). Biomass combustion is further complicated than both pyrolysis and gasification as the biomass initially pyrolyzed, later be partly gasified before this is fully gasified. Though, Eq. (1) express the complete global reaction of biomass oxidation (T. Reed, 1988).

$$
\mathrm{CH}_{1.4} \mathrm{O}_{0.6}+1.05 \mathrm{O}_{2}+3.95 \mathrm{~N}_{2} \rightarrow \mathrm{CO}_{2}+0.7 \mathrm{H}_{2} \mathrm{O}+3.95 \mathrm{~N}_{2} \quad \rightarrow(1)
$$

While $\mathrm{CH}_{1.4} \mathrm{O}_{0.6}$ is a standard procedure for woody biomass.

The nitrogen is shown in digression because this is an inert division from the air and does not involve during the reaction. Toward oxygen combustion of biomass, that would be absent. 


\subsection{Reduction/Gasification zone}

The gaseous mixture leaving the combustion zone mainly containing carbon dioxide, water vapor, inert nitrogen, and some amount of low molecular mass hydrocarbons, for example, methane, ethane, ethylene, etc., passes over that hot charcoal within this reduction region, which is frequently referred like gasification region (Diyoke et al., 2018). The first reaction within the reduction region is that of carbon dioxide through hot carbon for producing carbon monoxide. This is an endothermic process. It is referred to as the 'Boudouard' reaction (Eq. (2)).

$\mathrm{C}+\mathrm{CO}_{2} \rightarrow 2 \mathrm{CO} \quad \Delta \mathrm{H}=-1,72,600 \mathrm{~J} / \mathrm{mol} \rightarrow(2)$

Another essential reaction takes place among water vapour as well as carbon during the construction of carbon monoxide plus hydrogen as given by Eq. (3).

$\mathrm{C}+\mathrm{H}_{2} \mathrm{O} \rightarrow \mathrm{CO}+\mathrm{H}_{2} \quad \Delta \mathrm{H}=-1,31,400 \mathrm{~J} / \mathrm{mol} \rightarrow(3)$

Reaction (3) is called the water gas reaction. That is also an endothermic reaction and takes place between $600^{\circ} \mathrm{C}$ and $950^{\circ} \mathrm{C}$. As the reactions (2) and (3) are endothermic, the gas stream loses heat and the temperature drops in the reduction zone progressively. If surplus water is nearby inside the reduction region that so-called water shift reaction may to receives position (Reaction (4)).

$$
\mathrm{CO}+\mathrm{H}_{2} \mathrm{O} \rightarrow \mathrm{CO}_{2}+\mathrm{H}_{2} \quad \Delta \mathrm{H}=-41,200 \mathrm{~J} / \mathrm{mol} \quad \rightarrow(4)
$$

This is an exothermic reaction and is undesirable while it decreases the calorific value of gas. So, avoid the excess moisture in the fuel. The gaseous mixture leaving the biomass gasifier generally includes $\mathrm{CO}, \mathrm{H}_{2}, \mathrm{CO}_{2}$, nitrogen as well as water vapour. It may also contain 
some number of hydrocarbons such as $\mathrm{CH}_{4}, \mathrm{C}_{2} \mathrm{H}_{2}$, and $\mathrm{C}_{2} \mathrm{H}_{6}$, the amount of each may depend upon the configuration of the gasifier and is also dependent on the type of the biomass. Producer gas is also loaded with dust, tar and water vapour.

\section{Experimental studies}

Several researchers around the globe have carried out investigational studies on steam gasification using a range of configurations of gasifiers. These studies can be subdivided within two most important factions based on the type of biomass gasifier employed, that is, the fixed bed along with the fluidized bed.

\subsection{Fixed bed gasifiers}

During fixed bed gasifiers, the biomass is charged inside the gasifier at the start or intermittently. Based on the location of the gasifying agent, i.e. air, steam, enriched air with oxygen, air and steam bath, etc., they can be subdivided into the updraft, downdraft plus cross draft gasifiers. Due to the consumption of biomass in the combustion zone, biomass from another zone (reduction or pyrolysis depending upon the configuration of the gasifier) will move continually. Many researchers (Gordillo et al., 2009; Kraussler et al., 2018; Yan et al., 2018) have worked on biomass steam gasification using fixed bed gasification technology. Further, (Mudge et al., 1979) investigated the steam gasification like timber within the company as catalysts. Two processes in favour of timber/catalyst get in touch with were applied: dry integration concerning wooden and concrete catalyst, also impregnation from the wood through catalyst. Catalysts used were potassium carbonate, sodium carbonate, trona, as well as borax consecutively to their efficiency on the entire temperatures. 
Additionally (Barrows \& Elliott, 1984) developed a high-pressure reactor system and studied the method regarding lignin including biomass gasification at below temperatures $\left(100{ }^{\circ} \mathrm{C}-350{ }^{\circ} \mathrm{C}\right)$ and under tremendous pressure (upward to $\left.375 \mathrm{~atm}\right)$. The reactor provided the extraction of specimens for both tip and base regarding the reaction atmosphere throughout the operation. Additional, (Baker et al., 1987) concluded that nickel-dependent catalysts are useful for improving gas production by steam gasification concerning biomass through transforming tars, including different hydrocarbons over gas. Also, (Hanaoka et al., 2005a; Hanaoka et al., 2005b) studies on the hydrogen invention starting timbered biomass through steam gasification by a $\mathrm{CO}_{2}$ sorbent was carried out at air-steam gasification accepting a ceramic reactor with a temperature controller. In this experimental setup, the required quantity of biomass was fed to the reactor and external heating was provided using the furnace surrounding the ceramic reactor. He et al., (2009) studied the catalytic steam gasification from MSW to generate $\mathrm{H}_{2}$-enrich gas either syngas $\left(\mathrm{H}_{2}+\mathrm{CO}\right)$ including calcined dolomite being a catalyst within a bench-range downstream fixed bed reactor. The importance of the catalyst plus reactor temperature at outcome including product formation was investigated in the temperature limit of $750-950{ }^{0} \mathrm{C}$, including fumes over MSW proportion of 0.77 , as mass frequently interval rate about $1.29 \mathrm{~h}^{-1}$. Additional, (Gordillo \& Annamalai, 2010) proposed the results on gas interpretation collected by MS as a standard analysis $(E R=4.2$ and $S: F=0.4)$ as a function of the time. At fixed steam to fuel ratio (S: F), escalating the ER declines the $\mathrm{O}_{2}$ feed among the air from the underside that involves falling $\mathrm{T}_{\text {peak }}$ within combustion region; additional $\mathrm{H}_{2} \mathrm{O}$ concentration boosts. Further, Li et al. (2009a) developed a supported tri-metallic catalyst for the tar conversion and improved hydrogen generation under biomass steam gasification, which concentrates on inhibiting coke displacement also sintering effects to increase the existence of improved catalysts. Gordillo 
and Annamalai (2010) studied on the adiabatic rigid bed gasification for dairy biomass (DB) through the air as well as steam. DB like raw material used during gasification methods in favour of nearby supported power production could alleviate the ecological impact commencing DB fashioned within big US dairy farm also fossil-fuels releases, as biomass is $\mathrm{CO}_{2}$ unbiased petroleum. The current trials were executed via a modified small scale (10 KW) batch sort fixed bed counter flow vaporizer. The results have been concluded to facilitate the peak temperature $\left(\mathrm{T}_{\text {peak }}\right)$, energy conversion efficiency $(\mathrm{ECE})$, along with $\mathrm{CO}$ decrease, and $\mathrm{H}_{2}$ plus $\mathrm{CO}_{2}$ augment through increase into ER. The fixed bed gasifiers were listed being updraft and downdraft or cross-draft. In detailed they have addressed as below:

\subsubsection{Updraft design}

As we know, a fixed bed updraft gasifier does reflect as the most straightforward contour. Air (used as an oxidant) moves counterflow to the parent material. That is becoming as comparatively significant precipitation fuels (being large as $60 \%$ soaked data) and offers a massive quantity from tar plus pyrolysis outputs near the generated fumes (Gunarathne et al., 2014). Therefore, this arrangement is much supporting during straight flame purposes under which the fumes may be consumed in the absence of adequate (or some) gas sterilization either tar extraction. On behalf of power, otherwise fuels employment, inclusive gas purification could be needed. Updraft operations have moderately elevated carbon flux performances (small carbon/charcoal during the manufacture) as well as are fit in favour of tiny to the average range.

\subsubsection{Downdraft design}

Lv et al., 2007 have explained the different zones in a model figure in the downdraft gasifier. By using the figure, authors claimed that it is possible to identify the structure in 
addition to the operating conditions that can affect the gasifier. Air including fuel moves coexistence within the fixed bed downdraft gasifier (as the fuel runs enormously quieter compared to the air). Air used as an oxidant may start on the head by the fuel under the permitted centre configuration, either, also usually at a standard level over-vigorous command position like the raised-temperature oxidation region. Produce gas outlets typically close the base from the reactor following the reduction region. Fuel condensation specification is further decisive compared during the updraft configuration also would be < $30 \%$. The primary benefit concerning the downdraft gasifier holds promising during the lowering tar gas composition if correctly performed, employing fuel including suitable precipitation contented plus bit dimension. The operation gives carbonaceous char trash also is much filled during short-range $(\sim 15-500 \mathrm{~kW})$.

\subsection{Fluidized bed gasifier}

The fluidized bed reactors include a bed about comparatively tiny bits from the inorganic substance (usually dust either minute width ceramic grains or rocks). These beds are 'fluidized' through going warm oxidant up of the base. Single shreds are lifts via aerodynamic resistance and also display interrupted either entrained upon the gas stream on swiftness as that the friction strength grows similar upon either surpass the bit mass. During fluidized, each bed acts enormously similar to a fluid. While the bed medium is sufficiently warm, biomass does introduce both within the bed may also start as combust gasifier instead depend upon the quantity concerning available oxygen. Illustration concerning pilot-range fluidized bed gasification arrangement and results based on the S/B ratio (Meng et al., 2019). Caballero et al. (1997) used profitable steam better (nickel-based) catalysts to warm gas purification as well as to improve biomass gasification by steam-oxygen blends in their study. This gasifier adopted was a climatic plus bubbling fluidized bed including an inner width of 
about $15 \mathrm{~cm}$. Furthermore, a full stature of about $3.2 \mathrm{~m}$ was also successively fed by $5-20 \mathrm{~kg}$ concerning biomass/hour. Delgado et al. (1997) investigated the up-gradation of the fresh warm gas by a bubbling fluidized bed biomass carburettor applying economic calcined ores either stones downstream by that gasifier. Biomass conversion is completed by fumes (no atmosphere) on $750-780{ }^{\circ} \mathrm{C}$ including around $0.5-1.0 \mathrm{~kg}$ from biomass/hour. Exposed to the intense heat, the solids employed were dolomite $(\mathrm{MgO}-\mathrm{CaO}), \mathrm{CaO}$, and absolute $\mathrm{MgO}$. Gil et al. (1997) had examined within specification through the pilot plant system, the biomass gasification under a fluidized bed by steam- $\mathrm{O}_{2}$ mixes. The stock arrangement used in work presented involves gas, tarmac plus char provides gas formation $\left(\mathrm{H}_{2}, \mathrm{CO}, \mathrm{CO}_{2}, \mathrm{CH}_{4}\right.$, vapour plus heating charge, tarmac structure including substance within the chimney gas, and possible thermal performance, etc. García et al. $(2002 ; 1999)$ have studied steam gasification of pine sawdust during a fluidized bed on a comparatively low temperature around, $700{ }^{\circ} \mathrm{C}$. The Ni-Al substance applied was developed through co-precipitation and calcined about 750 ${ }^{\circ} \mathrm{C}$ for $3 \mathrm{~h}$. They have analyzed this impact on specific catalyst weight/biomass run speed $(\mathrm{W} / \mathrm{mb}$ ) including steam/biomass $(\mathrm{S} / \mathrm{B})$ proportions upon the output. An augment from this W/mb proportion improves the entire gas, $\mathrm{H}_{2}, \mathrm{CO}$, also $\mathrm{CO}_{2}$ outputs, though $\mathrm{CH}_{4}$ plus $\mathrm{C}_{2}$ quantity was found to be reduced. An extension regarding the S/B proportion develops $\mathrm{H}_{2}$ and $\mathrm{CO}_{2}$ products. However, $\mathrm{CO}$ plus $\mathrm{CH}_{4}$ yields were found to decrease. $\mathrm{Lv}$ et al. (2003; 2004) studied biomass air-steam gasification under a fluidized bed towards hydrogen-enrich gas production. They introduced that gasifying agent (air) in this reactor of the below section concerning the reactor. Also, steam was united within the reactor beyond the biomass supplying position. Campoy et al. (2009) studied the influence of oxygen intensity during the gasification agent enhanced-air-steam biomass gasification experiments under a bubbling fluidized-bed gasification (FBG) manufactory. During the investigation, the oxygen 
contented within the improved air was raised to $21-40 \%$, pointing toward simulating FBG wherever enhanced air was generated through membranes. This stoichiometric proportion and S/B ratio were also increased from 0.24 to 0.38 and from 0 to 0.63 , respectively.

Pfeifer et al. (2009) showed the correlation from twin fluidized bed gasification concerning biomass, including the absence of a particular carrier from $\mathrm{CO}_{2}$ of the gasification towards this ignition reactor. This coupled fluidized bed equipment presented required temperature during steam gasification with flowing warm bed substance which is burned under a different fluidized bed reactor with the combustion from remaining biomass char. Xiao et al. (2010b) utilized a considerable amount from animal dung as a cause of renewable energy should possible to decrease disposal obstacles also linked infection problems. Gasification properties from the dung fertilizer execute this feasibility towards lowering heat gasification. The experiment was done to observe the energy-efficient move towards to hydrogen-rich syngas from fertilizer is represented at comparatively below heat, around 600 ${ }^{0} \mathrm{C}$, in a consecutive-feeding fluidized bed reactor. That impacts on catalyst show, reactor heat, steam, plus reaction model toward the gas product, gas combination, including carbon regeneration performance, are addressed. This $\mathrm{Ni}-\mathrm{Al}_{2} \mathrm{O}_{3}$ catalyst concurrently encourages tar cracking and steam reforming as well. More significant heat provides more exceptional gas products and carbon reformation. De Andres et al. (2011b) studied the sewage mud gasification and detailed analyses were presented with an impressive fluidized bed activator employing an atmosphere plus air-steam hybrids being these gasifying factors. Dolomite, olivine including alumina were three tarmac deletion catalysts employed during biomass gasification exemption. A particular aim of the analysis was to receive this importance about specific three catalysts towards the outcome pattern plus tar composition through sewage refuse gasification. Michel et al. (2011a; 2011b) carried out their study on the Miscanthus X 
Giganteus (MXG), particularly within the horticultural area, though that research is the primary that trades by gasification within the plan to create syngas. Each catalytic steam gasification from MXG under a fluidized bed activator within the proximity from olivinebased reactants was examined. The Fluidized bed gasifiers are also classified as bubbling fluidized beds, circulating fluidized beds, dual-bed indirect as well as an entrained-bed gasifier.

\subsubsection{Bubbling fluidized bed gasifier}

Bubbling fluidized bed biomass gasifier (BFG) has comparatively sluggish rate air, oxygen and steam movement (linked through rotating fluid beds). The bed substance gathered into the below dense-bed section since the freeboard segment over this bed has a higher width plus deeper gas swiftness. Lim and Alimuddin (2008) performed an energy analysis and showed the schematic description of the operation, including the energy production of products on all steps of the operation. De Andres et al. (2011a) premeditated the sewage sludge gasification progression during bubbling fluidized bed gasifiers at a laboratory level. The variables examined were the ER, S/B proportion plus temperature. That ER fluctuated from $0.2-0.4$, the S/B of $0-1$ including the temperature from $750-850{ }^{\circ} \mathrm{C}$. Dual fluidized bed steam gasification is a pretty useful technique to generate a hydrogenenrich synthesis gas from biomass scraps (Igarashi et al., 1984). However, some problems must be resolved during the study of this type of reactor. The primary disadvantage of specific tools is to sustain the heat from the endothermic steam gasifier effects that are more significant compared to $1073 \mathrm{~K}$ to ensure an excellent metabolism performance. The heat carrier secures this of the exothermic flaming reactor toward the gasifier. This connection resistance within those two-reactor cells has not normally sufficient facade area to convey to that gasifier the (quite large) quantity about heat needed beyond while the temperature break 
by the combustor is insufficient. Consequently, the temperature needs to be mainly carried by the flow of sandy solid (Corella et al., 2007; Di Carlo et al., 2018).

\subsubsection{Circulating fluidized bed gasifier}

This circulating fluidized bed (CFB) works at high gas swiftness and gives more excellent regeneration rates as well as responses. Alternatively, a topside region, the reactor broadness resides typically consistent, that holds bed and fuel particles separated. This bed substance transferred upside by the fluidizing gas and moved above inside a storm that divides maximum of the shreds from the gas stream that are later re-injected inside the below section of bed. Usually, each fuel bits are tiny adequate to respond being brought over inside the tornado thoroughly, still in usage; high fuel shreds recirculate by bed mechanisms till tiny including delicate sufficient to be brought escape among the resulting gas exiting this storm or another detachment tool. The generation of hydrogen including liquid fuels as oxygen explosion CFB gasifiers are competitors ( $\mathrm{Li}$ et al., 2004).

\subsubsection{Dual-bed indirect gasifiers}

Indirect-temperature or allothermal, gasification operations deliver gas amidst light on no thinner, moreover, if the steam shot is applied, effects into remarkably more immense $\mathrm{H}_{2} / \mathrm{CO}$ proportions; shows this affirmative role towards the construction of liquid either vaporous energy transmitter. It is a leading scientific difficulty during allothermal gasifiers that the temperature variation occurs within this reactor (Karellas et al., 2012). General subsidiary gasifiers hold of dual fluidized bed (DFB) reactors. Oxidization happens inside one reactor plus heat is carried beside the burning powder while it passes through the gasification reactor - fresh powder including char run behind over the combustion container during re-heating. Auxiliary gasification concerning biomass under DFB vaporizers, for 
example, this Güssing gasifier either that biomass heat boiler reformer grows uniquely engaging during each transformation from biomass within hydrogen instead some other period fuel such as replacement natural gas $(\mathrm{SNG}), \mathrm{CH}_{4} \mathrm{OH}$ rather Fischer-Tropsch diesel combustible (Hamelinck \& Faaij, 2002).

\subsubsection{Entrained bed gasifier}

Entrained bed gasifiers (EFG) remain employed broadly via this petroleum enterprise to switch petroleum sediments (such as oil coke) to valuable outputs plus energy. The entrained run operations achieve maximum coke gasification. Palumbo et al. (2013) carried out leading-temperature steam gasification from biomass-methane compounds under an obliquely heated entrained stream reactor for examining this probability about testing the product configuration concerning the higher synthesis fumes outcomes: $\mathrm{H}_{2}, \mathrm{CO}, \mathrm{CO}_{2}$, and

$\mathrm{CH}_{4}$. Each $2^{3}$ factorial trial study was taken out and also correlated upon thermodynamic steadiness forecasts. Investigations have confirmed that this product gas arrangement is often reliant upon temperature. Outcomes endorsed that with two carbon-based reactants, it is feasible to check gas formation concerning the significant outputs. On $1500{ }^{\circ} \mathrm{C}$, that steadiness results correctly divined the synthesis gas composition plus it may be applied for design optimization from the syngas to downstream fluid fuel synthesis manufactory (Ismail et al., 2019).

\section{Steam gasification}

Gasification renovates fossil or non-fossil fuels (concrete, fluid, or gaseous) within valuable gases as well as chemicals (Basu, 2010). Gasification methods transform the flammable biomass gases which hold total energy which was already within the biomass. Gasification methods may be both straight (employing air either oxygen for produce heat by 
exothermic reactions) or complicated (carrying temperature over the reactor of the surface). That gas may be ignited to generate manufacturing housing heat preferentially, to speed motors towards mechanical either electrical energy, instead to make manufactured fuels. During the case of liquefaction, the bulky feedstock molecules are decayed into liquids having slighter molecules (Babu, 2008; Basu, 2010).

\subsection{The key parameters considered in the steam gasification:}

Biomass characteristics, equivalence ratio, moisture content, operating temperature, superficial velocity, gasifying agents, bit/particle dimension, gasification heat, S/B proportion steam flow speed/rate, reaction catalyst/reactant, and residence moment are some principal agents influencing the hydrogen generation methods including outcomes. We have discussed in detail about all the parameters of this study as given below.

\subsubsection{The consequences regarding biomass characteristics:}

Table 2 shows some $\mathrm{H}_{2}$ yields plus exergy performances during the hydrogen generation of steam gasification from various biomasses. The overall result concluded by the outcomes shown during the investigation is that this $\mathrm{H}_{2}$ yield plus these chemical exergies primarily resolves some exergy performance of hydrogen generation of steam gasification from biomass. The reason behind this is that few additional fuels can generate significant leading $\mathrm{H}_{2}$ products to obtain magnificent exergy performances, that is, pine sawdust should produce an $\mathrm{H}_{2}$ about $72.83 \mathrm{~mol} / \mathrm{kg}$, furthermore this exergy response was $79.58 \%$ (Moghtaderi, 2007).

\subsubsection{Equivalence ratio:}

The ER is a significant criterion that examines this exact air/biomass proportion split with the stoichiometric air/biomass proportion, such as given below: 


$$
E R=\left(F_{\text {oxidant }} / F_{\text {biomass }}\right) /\left(F_{\text {oxidant } \text {,stoichiometry }} / F_{\text {biomass })}\right.
$$

By stoichiometric oxidation, either complete combustion is a leading position on ER $=1$. Each ER completely controls this kind concerning gasification outcomes. It is imperative since an enormous ER value appears under a weaker density like $\mathrm{H}_{2}$ plus $\mathrm{CO}$ in addition to near a more significant $\mathrm{CO}_{2}$ content inside the produced gas. So, a more fabulous ER reduces this steaming rate concerning the synthesis gas. Raising the ER too has a beneficial impact towards decreasing tar production provided that a higher probability of oxygen reacts by volatiles. Further, Meng et al. (2018) have carried out their study on olivine catalysts for the oxygen reservoir during biomass gasification. That scale about ER of $0.28-0.32$ choose during this bed substance is silica dust, although for 1100-olivine bed material the ER scale was used $0.25-0.29$. This difference in ER is accomplished by varying the supply quantity. They did these inspections at $850{ }^{\circ} \mathrm{C}$. In silica sand, the carbon regeneration, including the proportion from $\mathrm{CO}_{2}$ into $\mathrm{CO}$ improves significantly by raising ER, showing unusual reaction is extra inclined towards the combustion method. While these ER rises, the oxygen engagement into this reaction progress, creating extra coke to respond including oxygen to develop $\mathrm{CO}_{2}$, following a reduction within the congregation concerning flammable gas (Makwana et al., 2015). As 1100-olivine, the carbon regeneration, including rate evolution from gases, are comparable by the silica powder. These variations are which tar contains are all considerably below the new operations. Also, according to (Kinoshita et al., 1994), the ER raises, the phenols within tar will sink; and the content about benzene, naphthalene, 3- and 4ring composites will increase.

\subsubsection{Moisture content:}


As we know that the high precipitation is a vital property of biomass. Each origin from plant biomass consumes moisture by the earth as well as drives it within the sapwood. This moisture moves towards these leaves within the narrow sections. Also, the photosynthesis reactions inside these leaves adopt few from it, moreover remain releasing to the environment through transpiration. The biomass decay rate reduces with an increment in moisture content. Toward more excellent moisture at ease of biomass, this energy necessary towards drying rises also decreases each biomass pyrolysis. This biomass moisture contented dramatically affects both processes from the gasifier plus unique nature regarding this commodity gas.

\subsubsection{Operating temperature:}

At the leading working temperature $\left(>800{ }^{\circ} \mathrm{C}\right)$, the gasifier is suggested to obtain a high carbon regeneration of the biomass and low tar content. With the increment within the temperature, flammable gas contented, gas acquiesce, hydrogen, as well as heating rate every one of improved notably, at the same time as the tar comfortable reduced clearly. In favour of hydrogen generation during a biomass steam gasification procedure, heat is an essential determinant because the hydrogen composition reactions are endothermic responses. So, at leading gasification, heat accordingly supports the reproduction of hydrogen (Luo et al., 2009a; Luo et al., 2009b). As silica sand, this progresses from reaction temperature, the carbon regeneration improves; notably, the portion about $\mathrm{H}_{2}, \mathrm{CO}$ plus $\mathrm{CO}_{2}$ rises on differing levels. Moreover, each portion concerning $\mathrm{CH}_{4}$, including $\mathrm{C}_{2+}$ drops considerably. These outcomes show that particular improvement within temperature is favourable to this cracking from biomass raw material. Furthermore, it promotes the breaking of macromolecular vapours, including $\mathrm{CH}_{4}$ (Huang et al., 2012). During 1100-olivine, a specific portion about $\mathrm{CO}$ plus $\mathrm{H}_{2}$ improves by this progress of reaction temperature, including the section 
concerning $\mathrm{CH}_{4}$ drops by extension from reaction temperature. This aspect means that extra oxygen is required inside reaction in biomass gasification. This 1100-olivine near the reactor serves as an oxygen carrier primarily. Subsequently, it gives an oxygen reservoir towards this biomass gasification (Wang et al., 2017b). Earlier researches have revealed that the surface structure, along with reactivity from char shreds are responsive to the heating rate (Cetin et al., 2005; Xiao et al., 2010a). High-range gasification equipment, for example, entrained flow gasification, usually applies at high heat conversion to little fuel scraps. To obtain a complete perception of the method of char regeneration during scientifically appropriate conditions like high-temperature stipulations require chosen inside laboratory investigations (Li et al., 2018).

\subsubsection{Superficial velocity:}

Here, the superficial velocity (SV), is described as being a proportion from the synthesis gas generation flow on standard positions, including the smallest cross-sectional region concerning gasifier. Several contributors have shown in this field and observed that SV controls the gas generation rate, the gas power content, the fuel decay time and the power production of char plus tar composition rates. This is autonomous from reactor size, providing a straight correlation about gasifiers by several power productions (Bhavanam, 2011). Yamazaki et al. (2005) detailed in an excellent review this issue regarding the gasifier at less tar contention during yielder gas as well as large production received for SV estimate about approximately $0.4 \mathrm{Nm} / \mathrm{s}$. The lower value of the $\mathrm{SV}$ effect is a comparatively sluggish pyrolysis method by large yields of char also notable amounts from unburned resins.

\subsubsection{Gasifying agents:}

In the gasification process, the common encouraging approaches towards the transformation of hard biomass in producer gas include a thermochemical method (Meng et 
al., 2019). The characteristics of the yielder gas influences the reactor configuration and running circumstances. The investigations about gasifying agents lying on gasification exhibition too must be taken out, for example, air (Tinaut et al., 2008), $\mathrm{O}_{2}$ enhanced air (Wang et al., 2015b), $\mathrm{O}_{2}$ (Meng et al., 2018), steam (Pala et al., 2017), $\mathrm{CO}_{2}$ (Jeremiáš et al., 2017), air-stream (Wang et al., 2015a), as well as oxygen-steam (Hussein et al., 2017). Though, minimal investigations were taken to distinguish the influence from gasifying agents at gasification execution. (Wang et al., 2011) exploited the technological conditions about covered coke gasification applying air, air-stream, oxygen-riched fumes, including purified oxygen being gasifying factors at a two-step gasification operation. It has been observed that enhancement in the oxygen collection about the gasifying factor may improve low heating value (LHV) concerning the yielder gas near $30-40 \%$ but also reduces the air plus steam performance.

\subsubsection{Particle size:}

Gasification efficiency primarily lies in solar thermochemical reactor configurations (Kodama et al., 2017), functioning circumstances (Yadav \& Banerjee, 2016) as well as commencing carbonaceous substances (Molino et al., 2016). Furthermore, few investigations have approached the bio-oil result within the pyrolysis method from a broad diversity about sustainable carbonaceous raw materials, for example, rice peelings ( $\mathrm{Lu}$ et al., 2008), otherwise palm oil devastate (Abnisa et al., 2013). Wieckert et al. (2013) run a $150 \mathrm{kWth}$ packed-bed solar activator including six distinct carbonaceous garbage raw materials. This importance of particle attributes for instance, dimension, appearance, and density on the particle flow and flame dispersion were considered during a conventional gasification method (Holmgren et al., 2017). Dimension decrease developed the transformation methods since the production of higher active facade areas, produced an improved heat transferal circumstance. 24 
Further, Z'Graggen et al. (2006) showed that the minute bit dimensions exhibit an absolute control towards thermochemical effect flows. However, sufficient crushing is energy key, and carbonaceous substances by economic bulk density are probably dominated through feeding obstacles (Chuayboon et al., 2019).

\subsubsection{Steam/biomass ratio:}

The proportion of S/B may define the data energy conditions, exit gas property, plus the yield of outcomes. Improving S/B proportion may undoubtedly improve the rehabilitating, splitting water gas shift effects and drive towards higher hydrogen yield including simultaneous production of syngas beside a great calorific content (Parthasarathy \& Narayanan, 2014). Though there is an inception boundary behind, the enhancing S/B will produce more steam. Occurrence within specific enthalpy trial also decreases into system performance (Narváez et al., 1996). The problem requires improving this proportion of steam biomass gasification. While in every biomass steam gasification system, steam performs an essential part inside the hydrogen production effects, S/B proportion is also critical in influencing the hydrogen generation methods plus outcomes given in table 3 .

\subsubsection{Steam flow rate:}

This segment is focused on the steam flow rates with various biomass and $\mathrm{H}_{2}$ collection during hydrogen generation by steam gasification. Usually, the steam flow rate primarily grows and subsequently reduces this $\mathrm{H}_{2}$ yield (Ning et al., 2018). Because the steam flow rate resembles an S/B proportion that accordingly has comparable influences. The hydrogen produced is shown within a table 4.

\subsubsection{Reaction catalyst:}


Catalysts can present a lower-energy substitute route towards the development of the reaction. These catalysts employed within some biomass gasification are classified into an alkaline alloy, alumina plus zeolites, dolomites, limestone, $\mathrm{Ni}, \mathrm{Zn}$-based, as well as rarer metals, for example, Pt- including Ru-based. Amongst all, alkaline alloy oxides and dolomite, including Ni-based synergists, have been shown to advance the transformation reaction (Ni et al., 2006). Moreover, alumina silicates are determined for magnifying the char gasification efficiently, while Ni-based reactants are recognized to promote this change about volatile hydrocarbons (Corte et al., 1985). This is necessary for generating further effective plus efficient catalysts including the significant capability to enhance the characteristic as well as yield concerning aspired output when reducing the remaining char plus tar (Sikarwar et al., 2016).

\subsubsection{Residence time:}

Since the space residence time (that is opposite associated with this space velocity concerning reactants) is involved, the functioning inconstant influences the change (Hernández et al., 2010). Wang and Kinoshita (1993) demonstrated condition research about biomass gasification of kinetic design and also discovered that some regeneration expanded swiftly while the first $20 \mathrm{~s}$ of the manner, and after that, chemical effects began to progress further deliberately. Chen et al. (2003) achieved the spacious residence period like the gaseous stage affected absolutely at the pyrolysis gas product. Murakami et al. (2007) noted improvement during the space-period drive through growth into the performance concerning the gasification method by a binary fluidized bed activator. Chamberlin et al. (2018) perceived that the orders of the residence times were less disseminated, and the ends were less asserted when the average residence times were lower, and the mass flux rates were soaring. This recommends that greater process control might be accomplished by working 
shorter residence times/greater mass flow rates coupled with further maximum (higher or lower) temperatures. This should provide a more uniform product in heaters, coolers, dryers, terriers, gasifiers and additional reactors.

\section{The technical challenges and economic potential of the different gasification technologies:}

The important guidelines which have to be discussed when choosing a gasification system are: (i) initial expenses, (ii) managing and sustaining, (iii) strong gasifier arrangement without moving components, and (iv) maximal restriction of biomass raw material conditioning, for example drying, detachment, dimension reducing, or pelletization. By a correlation among fixed and fluidized bed reactors-based upon technology, application of substance and power, atmosphere, and economy-it has been confirmed that there is recess utilisation for these two reactors. Though, choice of an appropriate gasifier configuration needs absolute research of plenty of different constituents, with the biomass raw material physicochemical characteristics, the feature of product gas needed, the heating system (allothermal or autothermal method), and the numerous working variables associated. The characteristics of a fluidized bed reactor which resembles light engaging are the extra energy costs needed for biomass bit size conversion, commonly with a further complicated configuration and performance. Bit size conversion also happens in the development of powder. Catalyst depreciation is the main concern in fluidized bed gasifier and needs the improvement of each economic, nontoxic catalyst including comparatively excellent resistance to reduction, or extra effective and strong formulations based on transition elements or noble elements which are very durable to coking, sintering and sulphur poisoning, and are well friction-resistant (Richardson et al., 2012). It is assumed that large plant expenses offer fluidized bed gasification inexpensive on the 5-10 MW range. On the other hand, fixed bed reactors have neither or very less moving components, and all are, 
accordingly, well flexible for the generation of low calorific value (LCV) gas during shortrange power production plants among gas turbines. The main significant factors influencing such activity signs are reaction temperature, pressure, gasifying agent, catalyst, ER, and residence time. It can be emphasised that fluidized bed reactors, applying steam as gasifying agents as well as catalysts for in-bed tar reforming are the promising technologies during the evolution of extremely valuable biomass gasifier systems assigned to syngas generation (Richardson et al., 2015).

\section{Future prospects}

The strategy of novel innovative gasification reactor ideas still has to be followed to accomplish the challenging single-step manufacture of a good-quality syngas derived by biomass gasification. The execution of such advanced biomass gasification innovation ideas is pedestrian of observation as it could be one of the most hopeful paths of the manufacture prices related to syngas and $\mathrm{H}_{2}$ resultant by biomass. Hydrogen generation by biomass has substantial obstacles because there are no developed technology explanations. Overall it can be declared, that toward implementation of biomass gasification-supported $\mathrm{H}_{2}$ production, administrative aid and grants are required. Particularly initially years of the progress towards market development and durable performance and production, federal support is needed. It is understood that in the coming day's biomass can grow as a significant renewable reservoir of hydrogen. Owing to these environmental advantages, this portion of the hydrogen of biomass into the automotive fuel business will become active during the subsequent years. So, the gasification of biomass has been recognized as a potential way towards generating

sustainable hydrogen that is useful for employing biomass reserves. Fumes rebuilding concerning natural gas, including gasification of biomass, would grow this powerful technology over the edge of the 21 st era. 


\section{Conclusion}

This review reports on the existing investigation focused in this area and pointed numerous potential approaches which might be applied. A few promising key parameters that are considered during production of $\mathrm{H}_{2}$ enriched gases in the steam gasification have been discussed, including ER, S/B ratio, gasifying agent, reaction catalyst etc. The processes including high dependability, flexibility, and competence within cogeneration of energy assets from the conversion of biomass. Some optimal options of technology towards an assigned task will depend upon various circumstances including raw material availability, outline economy and environmental affairs including lifecycle evaluation factors towards the aspired product.

Acknowledgement: The authors gratefully acknowledge the financial support of the National Natural Science Foundation of China (21962008, 51464028), Candidate Talents Training Fund of Yunnan Province (2017PY269SQ, 2018HB007), and Yunnan Ten Thousand Talents Plan Young \& Elite Talents Project (YNWR-QNBJ-2018-346). 


\section{References:}

[1]. Abnisa, F., Arami-Niya, A., Daud, W.M.A.W., Sahu, J.N. 2013. Characterization of Bio-oil and Bio-char from Pyrolysis of Palm Oil Wastes. BioEnergy Research 6(2), 830-840.

[2]. Acharya, B., Dutta, A., Basu, P. 2010. An investigation into steam gasification of biomass for hydrogen enriched gas production in presence of $\mathrm{CaO}$. Int. J. Hydrogen Energy 35(4), 1582-1589.

[3]. Ali, D.A., Gadalla, M.A., Abdelaziz, O.Y., Hulteberg, C.P., Ashour, F.H. 2017. Cogasification of coal and biomass wastes in an entrained flow gasifier: Modelling, simulation and integration opportunities. J. Nat. Gas Eng. 37, 126-137.

[4]. Alipour Moghadam, R., Yusup, S., Azlina, W., Nehzati, S., Tavasoli, A. 2014. Investigation on syngas production via biomass conversion through the integration of pyrolysis and air-steam gasification processes. Energ. Convers. Manage. 87, 670-675.

[5]. Amoah, J., Kahar, P., Ogino, C., Kondo, A. 2019. Bioenergy and Biorefinery: feedstock, biotechnological conversion and products. Biotechnol. J. 0(ja), 1800494.

[6]. Arregi, A., Lopez, G., Amutio, M., Artetxe, M., Barbarias, I., Bilbao, J., Olazar, M. 2018. Role of operating conditions in the catalyst deactivation in the in-line steam reforming of volatiles from biomass fast pyrolysis. Fuel 216, 233-244.

[7]. Babu, B.V. 2008. Biomass pyrolysis: a state-of-the-art review. Biofuels, Bioprod. Bioref. 2, 393-414.

[8]. Baker, E.G., Mudge, L.K., Brown, M.D. 1987. Steam gasification of biomass with nickel secondary catalysts. Ind. Eng. Chem. Res. 26(7), 1335-1339.

[9]. Barrows, R.D., Elliott, D.C. 1984. Analysis of chemical intermediates from lowtemperature steam gasification of biomass. Fuel 63(1), 4-8. 
[10]. Basu, P. 2010. Biomass Gasification and Pyrolysis: Practical Design and Theory. Academic Press.

[11]. Bechtle, P., Schelbergen, M., Schmehl, R., Zillmann, U., Watson, S. 2019. Airborne wind energy resource analysis. Renew. Energy 141, 1103-1116.

[12]. Bhavanam, D.A. 2011. Biomass Gasification Processes in Downdraft Fixed Bed Reactors: A Review. Int J Chem Eng Appl. 2, 425-433.

[13]. Bhave, A.G. 2001. Technical notes. Intensive workshop on - Testing Evaluation of Biomass Gasifier Systems and Related Laboratory Investigation, April 2001, Vallabhvidhyanagar.

[14]. Bridgwater, A.V. 2002. Bio-Energy in: Gasification. Birmingham (UK).

[15]. Caballero, M.A., Aznar, M.P., Gil, J., Martín, J.A., Francés, E., Corella, J. 1997. Commercial Steam Reforming Catalysts To Improve Biomass Gasification with Steam-Oxygen Mixtures. 1. Hot Gas Upgrading by the Catalytic Reactor. Ind. Eng. Chem. Res. 36(12), 5227-5239.

[16]. Campoy, M., Gómez-Barea, A., Vidal, F.B., Ollero, P. 2009. Air-steam gasification of biomass in a fluidised bed: Process optimisation by enriched air. Fuel Process. Technol. 90(5), 677-685.

[17]. Cetin, E., Gupta, R., Moghtaderi, B. 2005. Effect of pyrolysis pressure and heating rate on radiata pine char structure and apparent gasification reactivity. Fuel 84(10), 13281334.

[18]. Chamberlin, C., Carter, D., Jacobson, A. 2018. Measuring residence time distributions of wood chips in a screw conveyor reactor. Fuel Process. Technol. 178, 271-282. 
[19]. Chen, G., Andries, J., Luo, Z., Spliethoff, H. 2003. Biomass pyrolysis/gasification for product gas production: the overall investigation of parametric effects. Energ. Convers. Manage. 44(11), 1875-1884.

[20]. Chuayboon, S., Abanades, S., Rodat, S. 2018. Experimental analysis of continuous steam gasification of wood biomass for syngas production in a high-temperature particle-fed solar reactor. Chem. Eng. Process.- Process Intens. 125, 253-265.

[21]. Chuayboon, S., Abanades, S., Rodat, S. 2019. Insights into the influence of biomass feedstock type, particle size and feeding rate on thermochemical performances of a continuous solar gasification reactor. Renew. Energy 130, 360-370.

[22]. Corella, J., Toledo, J.M., Molina, G. 2007. A Review on Dual Fluidized-Bed Biomass Gasifiers. Ind. Eng. Chem. Res. 46(21), 6831-6839.

[23]. Corte, P., Lacoste, C., Traverse, J.P. 1985. Gasification and catalytic conversion of biomass by flash pyrolysis. J Anal Appl Pyrolysis 7(4), 323-335.

[24]. Curtis, L.J., Miller, D.J. 1988. Transport Model with Radiative Heat Transfer for Rapid Cellulose Pyrolysis. Ind. Eng. Chem. Res. 27, 1775-1783.

[25]. de Andrés, J.M., Narros, A., Rodríguez, M.E. 2011a. Air-steam gasification of sewage sludge in a bubbling bed reactor: Effect of alumina as a primary catalyst. Fuel Process. Technol. 92(3), 433-440.

[26]. de Andrés, J.M., Narros, A., Rodríguez, M.E. 2011b. Behaviour of dolomite, olivine and alumina as primary catalysts in air-steam gasification of sewage sludge. Fuel 90(2), 521-527.

[27]. de Sales, C.A.V.B., Maya, D.M.Y., Lora, E.E.S., Jaén, R.L., Reyes, A.M.M., González, A.M., Andrade, R.V., Martínez, J.D. 2017. Experimental study on biomass (eucalyptus spp.) 
gasification in a two-stage downdraft reactor by using mixtures of air, saturated steam and oxygen as gasifying agents. Energ. Convers. Manag. 145, 314-323.

[28]. Delgado, J., Aznar, M.P., Corella, J. 1997. Biomass Gasification with Steam in Fluidized Bed: Effectiveness of $\mathrm{CaO}, \mathrm{MgO}$, and $\mathrm{CaO}-\mathrm{MgO}$ for Hot Raw Gas Cleaning. Ind. Eng. Chem. Res. 36(5), 1535-1543.

[29]. Di Carlo, A., Moroni, M., Savuto, E., Pallozzi, V., Bocci, E., Di Lillo, P. 2018. Cold model testing of an innovative dual bubbling fluidized bed steam gasifier. Chem. Eng. J. 377(1), 119689.

[30]. Diyoke, C., Gao, N., Aneke, M., Wang, M., Wu, C. 2018. Modelling of down-draft gasification of biomass - An integrated pyrolysis, combustion and reduction process. Appl. Therm. Eng. 142, 444-456.

[31]. Dogru, M., Howarth, C.R., Akay, G., Keskinler, B., Malik, A.A. 2002. Gasification of hazelnut shells in a downdraft gasifier. Energy 27(5), 415-427.

[32]. Fortunato, B., Brunetti, G., Camporeale, S.M., Torresi, M., Fornarelli, F. 2017. Thermodynamic model of a downdraft gasifier. Energ. Convers. Manag. 140, 281294.

[33]. Fremaux, S., Beheshti, S.-M., Ghassemi, H., Shahsavan-Markadeh, R. 2015. An experimental study on hydrogen-rich gas production via steam gasification of biomass in a research-scale fluidized bed. Energ. Convers. Manag. 91, 427-432.

[34]. Gai, C., Guo, Y., Liu, T., Peng, N., Liu, Z. 2016. Hydrogen-rich gas production by steam gasification of hydrochar derived from sewage sludge. Int. J. Hydrogen Energy 41(5), 3363-3372. 
[35]. Garcia, L., Benedicto, A., Romeo, E., Salvador, M.L., Arauzo, J., Bilbao, R. 2002. Hydrogen Production by Steam Gasification of Biomass Using Ni-Al Coprecipitated Catalysts Promoted with Magnesium. Energy Fuels 16(5), 1222-1230.

[36]. García, L., Salvador, M.L., Arauzo, J., Bilbao, R. 1999. Catalytic Steam Gasification of Pine Sawdust. Effect of Catalyst Weight/Biomass Flow Rate and Steam/Biomass Ratios on Gas Production and Composition. Energy Fuels 13(4), 851-859.

[37]. Gil, J., Aznar, M.P., Caballero, M.A., Francés, E., Corella, J. 1997. Biomass Gasification in Fluidized Bed at Pilot Scale with Steam-Oxygen Mixtures. Product Distribution for Very Different Operating Conditions. Energy Fuels 11(6), 1109-1118.

[38]. Gordillo, G., Annamalai, K. 2010. Adiabatic fixed bed gasification of dairy biomass with air and steam. Fuel 89(2), 384-391.

[39]. Gordillo, G., Annamalai, K., Carlin, N. 2009. Adiabatic fixed-bed gasification of coal, dairy biomass, and feedlot biomass using an air-steam mixture as an oxidizing agent. Renew. Energy 34(12), 2789-2797.

[40]. Guedes, R.E., Luna, A.S., Torres, A.R. 2018. Operating parameters for bio-oil production in biomass pyrolysis: A review. J. Anal. Appl. Pyrolysis 129, 134-149.

[41]. Gunarathne, D.S., Mueller, A., Fleck, S., Kolb, T., Chmielewski, J.K., Yang, W., Blasiak, W. 2014. Gasification characteristics of steam exploded biomass in an updraft pilot scale gasifier. Energy 71, 496-506.

[42]. Hamelinck, C.N., Faaij, A.P.C. 2002. Future prospects for production of methanol and hydrogen from biomass. J. Power Sources 111(1), 1-22.

[43]. Hanaoka, T., Inoue, S., Uno, S., Ogi, T., Minowa, T. 2005a. Effect of woody biomass components on air-steam gasification. Biomass Bioenergy 28(1), 69-76. 
[44]. Hanaoka, T., Yoshida, T., Fujimoto, S., Kamei, K., Harada, M., Suzuki, Y., Hatano, H., Yokoyama, S.-y., Minowa, T. 2005b. Hydrogen production from woody biomass by steam gasification using a sorbent. Biomass Bioenergy 28(1), 63-68.

[45]. He, M., Hu, Z., Xiao, B., Li, J., Guo, X., Luo, S., Yang, F., Feng, Y., Yang, G., Liu, S. 2009. Hydrogen-rich gas from catalytic steam gasification of municipal solid waste (MSW): Influence of catalyst and temperature on yield and product composition. Int. J. Hydrogen Energy 34(1), 195-203.

[46]. Hernández, J.J., Aranda-Almansa, G., Bula, A. 2010. Gasification of biomass wastes in an entrained flow gasifier: Effect of the particle size and the residence time. Fuel Process. Technol. 91(6), 681-692.

[47]. Holmgren, P., Wagner, D.R., Strandberg, A., Molinder, R., Wiinikka, H., Umeki, K., Broström, M. 2017. Size, shape, and density changes of biomass particles during rapid devolatilization. Fuel 206, 342-351.

[48]. Huang, B.-S., Chen, H.-Y., Chuang, K.-H., Yang, R.-X., Wey, M.-Y. 2012. Hydrogen production by biomass gasification in a fluidized-bed reactor promoted by an $\mathrm{Fe} / \mathrm{CaO}$ catalyst. Int. J. Hydrogen Energy 37(8), 6511-6518.

[49]. Hussein, M.S., Burra, K.G., Amano, R.S., Gupta, A.K. 2017. Effect of oxygen addition in steam gasification of chicken manure. Fuel 189, 428-435.

[50]. Igarashi, M., Hayafune, Y., Makishima, K., Nakagawa, Y., Sugamiya, R. 1984. Pyrolysis of Municipal Solid Waste in Japan. J. Energy Resour. Technol. 106(3), 377-382.

[51]. Ismail, W.M.S.W., Mohd Thaim, T., Abdul Rasid, R. 2019. Biomass gasification of oil palm fronds (OPF) and Koompassia malaccensis (Kempas) in an entrained flow gasifier: A performance study. Biomass Bioenergy 124, 83-87. 
[52]. Jeremiáš, M., Pohořelý, M., Svoboda, K., Manovic, V., Anthony, E.J., Skoblia, S., Beňo, Z., Šyc, M. 2017. Gasification of biomass with $\mathrm{CO} 2$ and $\mathrm{H} 2 \mathrm{O}$ mixtures in a catalytic fluidised bed. Fuel 210, 605-610.

[53]. Karellas, S., Panopoulos, K.D., Panousis, G., Rigas, A., Karl, J., Kakaras, E. 2012. An evaluation of Substitute natural gas production from different coal gasification processes based on modeling. Energy 45(1), 183-194.

[54]. Khan, Z., Yusup, S., Ahmad, M.M., Rashidi, N.A. 2014. Integrated catalytic adsorption (ICA) steam gasification system for enhanced hydrogen production using palm kernel shell. Int. J. Hydrogen Energy 39(7), 3286-3293.

[55]. Kinoshita, C.M., Wang, Y., Zhou, J. 1994. Tar formation under different biomass gasification conditions. J. Anal. Appl. Pyrolysis 29(2), 169-181.

[56]. Kodama, T., Bellan, S., Gokon, N., Cho, H.S. 2017. Particle reactors for solar thermochemical processes. Solar Energy 156, 113-132.

[57]. Kraussler, M., Binder, M., Schindler, P., Hofbauer, H. 2018. Hydrogen production within a polygeneration concept based on dual fluidized bed biomass steam gasification. Biomass Bioenergy 111, 320-329.

[58]. La Villetta, M., Costa, M., Massarotti, N. 2017. Modelling approaches to biomass gasification: A review with emphasis on the stoichiometric method. Renew Sustain. Energy Rev. 74, 71-88.

[59]. Li, J., Liu, J., Liao, S., Yan, R. 2010. Hydrogen-rich gas production by air-steam gasification of rice husk using supported nano-NiO/Y-Al2O3 catalyst. Int. J. Hydrogen Energy 35(14), 7399-7404. 
[60]. Li, J., Xiao, B., Yan, R., Xu, X. 2009a. Development of a supported tri-metallic catalyst and evaluation of the catalytic activity in biomass steam gasification. Bioresour. Technol. 100(21), 5295-5300.

[61]. Li, J., Yin, Y., Zhang, X., Liu, J., Yan, R. 2009b. Hydrogen-rich gas production by steam gasification of palm oil wastes over supported tri-metallic catalyst. Int. J. Hydrogen Energy 34(22), 9108-9115.

[62]. Li, Q., Liu, Y., Guo, S., Zhou, H. 2017. Solar energy storage in the rechargeable batteries. Nano Today 16, 46-60.

[63]. Li, T., Niu, Y., Wang, L., Shaddix, C., Løvås, T. 2018. High temperature gasification of high heating-rate chars using a flat-flame reactor. Appl. Energy 227, 100-107.

[64]. Li, W., Li, Q., Chen, R., Wu, Y., Zhang, Y. 2014. Investigation of hydrogen production using wood pellets gasification with steam at high temperature over $800^{\circ} \mathrm{C}$ to $1435^{\circ} \mathrm{C}$. Int. J. Hydrogen Energy 39(11), 5580-5588.

[65]. Li, X.T., Grace, J.R., Lim, C.J., Watkinson, A.P., Chen, H.P., Kim, J.R. 2004. Biomass gasification in a circulating fluidized bed. Biomass Bioenergy 26(2), 171-193.

[66]. Lim, M.T., Alimuddin, Z. 2008. Bubbling fluidized bed biomass gasificationPerformance, process findings and energy analysis. Renew. Energy 33(10), 23392343.

[67]. Loisel, R., Sanchez-Angulo, M., Schoefs, F., Gaillard, A. 2018. Integration of tidal range energy with undersea pumped storage. Renew. Energy 126, 38-48.

[68]. Lopez, G., Artetxe, M., Amutio, M., Alvarez, J., Bilbao, J., Olazar, M. 2018. Recent advances in the gasification of waste plastics. A critical overview. Renew. Sustain. Energy Rev. 82, 576-596. 
[69]. Lu, Q., Yang, X.-I., Zhu, X.-f. 2008. Analysis on chemical and physical properties of biooil pyrolyzed from rice husk. J. Anal. Appl. Pyrolysis 82(2), 191-198.

[70]. Luo, S., Xiao, B., Guo, X., Hu, Z., Liu, S., He, M. 2009a. Hydrogen-rich gas from catalytic steam gasification of biomass in a fixed bed reactor: Influence of particle size on gasification performance. Int. J. Hydrogen Energy 34(3), 1260-1264.

[71]. Luo, S., Xiao, B., Hu, Z., Liu, S., Guo, X., He, M. 2009b. Hydrogen-rich gas from catalytic steam gasification of biomass in a fixed bed reactor: Influence of temperature and steam on gasification performance. Int. J. Hydrogen Energy 34(5), 2191-2194.

[72]. Lv, P., Chang, J., Xiong, Z., Huang, H., Wu, C., Chen, Y., Zhu, J. 2003. Biomass Air-Steam Gasification in a Fluidized Bed to Produce Hydrogen-Rich Gas. Energy Fuels 17(3), 677-682.

[73]. Lv, P., Yuan, Z., Ma, L., Wu, C., Chen, Y., Zhu, J. 2007. Hydrogen-rich gas production from biomass air and oxygen/steam gasification in a downdraft gasifier. Renew. Energy 32(13), 2173-2185.

[74]. Lv, P.M., Xiong, Z.H., Chang, J., Wu, C.Z., Chen, Y., Zhu, J.X. 2004. An experimental study on biomass air-steam gasification in a fluidized bed. Bioresour. Technol. 95(1), 95101.

[75]. Makwana, J.P., Joshi, A.K., Athawale, G., Singh, D., Mohanty, P. 2015. Air gasification of rice husk in bubbling fluidized bed reactor with bed heating by conventional charcoal. Bioresour. Technol. 178, 45-52.

[76]. Manochio, C., Andrade, B.R., Rodriguez, R.P., Moraes, B.S. 2017. Ethanol from biomass: A comparative overview. Renew. Sustain. Energy Rev. 80, 743-755. 
[77]. Masmoudi, M.A., Halouani, K., Sahraoui, M. 2017. Comprehensive experimental investigation and numerical modeling of the combined partial oxidation-gasification zone in a pilot downdraft air-blown gasifier. Energ. Convers. Manag. 144, 34-52.

[78]. Meng, F., Ma, Q., Wang, H., Liu, Y., Wang, D. 2019. Effect of gasifying agents on sawdust gasification in a novel pilot scale bubbling fluidized bed system. Fuel 249, 112-118.

[79]. Meng, F., Meng, J., Zhang, D. 2018. Influence of higher equivalence ratio on the biomass oxygen gasification in a pilot scale fixed bed gasifier. J. Renew. Sustain. Energy 10(5), 053101.

[80]. Michel, R., Rapagnà, S., Burg, P., Mazziotti di Celso, G., Courson, C., Zimny, T., Gruber, R. 2011a. Steam gasification of Miscanthus X Giganteus with olivine as catalyst production of syngas and analysis of tars (IR, NMR and GC/MS). Biomass Bioenergy 35(7), 2650-2658.

[81]. Michel, R., Rapagnà, S., Di Marcello, M., Burg, P., Matt, M., Courson, C., Gruber, R. 2011b. Catalytic steam gasification of Miscanthus X giganteus in fluidised bed reactor on olivine based catalysts. Fuel Process. Technol. 92(6), 1169-1177.

[82]. Moghtaderi, B. 2007. Effects of controlling parameters on production of hydrogen by catalytic steam gasification of biomass at low temperatures. Fuel 86(15), 2422-2430.

[83]. Molino, A., Chianese, S., Musmarra, D. 2016. Biomass gasification technology: The state of the art overview. J. Energy Chem. 25(1), 10-25.

[84]. Mudge, L.K., Sealock Jr, L.J., Weber, S.L. 1979. Catalyzed steam gasification of biomass. J. Anal. Appl. Pyrolysis 1(2), 165-175. 
[85]. Murakami, T., Xu, G., Suda, T., Matsuzawa, Y., Tani, H., Fujimori, T. 2007. Some process fundamentals of biomass gasification in dual fluidized bed. Fuel 86(1), 244-255.

[86]. Murugan, P.C., Joseph Sekhar, S. 2017. Species - Transport CFD model for the gasification of rice husk (Oryza Sativa) using downdraft gasifier. Comput. Electron. Agr. 139, 33-40.

[87]. Narváez, I., Orío, A., Aznar, M.P., Corella, J. 1996. Biomass Gasification with Air in an Atmospheric Bubbling Fluidized Bed. Effect of Six Operational Variables on the Quality of the Produced Raw Gas. Ind. Eng. Chem. Res. 35(7), 2110-2120.

[88]. Navakas, R., Saliamonas, A., Striūgas, N., Džiugys, A., Paulauskas, R., Zakarauskas, K. 2018. Effect of producer gas addition and air excess ratio on natural gas flame luminescence. Fuel 217, 478-489.

[89]. Ni, M., Leung, D.Y.C., Leung, M.K.H., Sumathy, K. 2006. An overview of hydrogen production from biomass. Fuel Process. Technol. 87(5), 461-472.

[90]. Ning, S., Jia, S., Ying, H., Sun, Y., Xu, W., Yin, H. 2018. Hydrogen-rich syngas produced by catalytic steam gasification of corncob char. Biomass Bioenergy 117, 131-136.

[91]. Nipattummakul, N., Ahmed, I.I., Kerdsuwan, S., Gupta, A.K. 2010. Hydrogen and syngas production from sewage sludge via steam gasification. Int. J. Hydrogen Energy 35(21), 11738-11745.

[92]. Pala, L.P.R., Wang, Q., Kolb, G., Hessel, V. 2017. Steam gasification of biomass with subsequent syngas adjustment using shift reaction for syngas production: An Aspen Plus model. Renew. Energy 101, 484-492. 
[93]. Palumbo, A.W., Jorgensen, E.L., Sorli, J.C., Weimer, A.W. 2013. Co-processing methane in high temperature steam gasification of biomass. Bioresour. Technol. 128(0), 553559.

[94]. Parthasarathy, P., Narayanan, K.S. 2014. Hydrogen production from steam gasification of biomass: Influence of process parameters on hydrogen yield - A review. Renew. Energy 66, 570-579.

[95]. Pfeifer, C., Puchner, B., Hofbauer, H. 2009. Comparison of dual fluidized bed steam gasification of biomass with and without selective transport of CO2. Chem. Eng. Sci. 64(23), 5073-5083.

[96]. Richardson, Y., Blin, J., Julbe, A. 2012. A short overview on purification and conditioning of syngas produced by biomass gasification: Catalytic strategies, process intensification and new concepts. Prog. Energy Combust. Sci. 38(6), 765-781.

[97]. Richardson, Y., Drobek, M., Julbe, A., Blin, J., Pinta, F. 2015. Chapter 8 - Biomass Gasification to Produce Syngas. in: Recent Advances in Thermo-Chemical Conversion of Biomass, (Eds.) A. Pandey, T. Bhaskar, M. Stöcker, R.K. Sukumaran, Elsevier. Boston, pp. 213-250.

[98]. Rony, A.H., Mosiman, D., Sun, Z., Qin, D., Zheng, Y., Boman, J.H., Fan, M. 2018. A Novel Solar Powered Biomass Pyrolysis Reactor for Producing Fuels and Chemicals. J. Anal. Appl. Pyrolysis 132, 19-32.

[99]. Sikarwar, V.S., Zhao, M., Clough, P., Yao, J., Zhong, X., Memon, M.Z., Shah, N., Anthony, E.J., Fennell, P.S. 2016. An overview of advances in biomass gasification. Energy Environ. Sci. 9(10), 2939-2977.

[100]. Singer, C.J. 1958. History of Technology. Claderon Press, Oxford. 
[101]. Singha, A.S., Thakur, V.K. 2009. Fabrication and Characterization of H. sabdariffa Fiber-Reinforced Green Polymer Composites. Polym. Plast. Technol. Eng. 48(4), 482487.

[102]. Song, Y.-C., Li, Q.-t., Li, F.-z., Wang, L.-S., Hu, C.-C., Feng, J., Li, W.-y. 2019. Pathway of biomass-potassium migration in co-gasification of coal and biomass. Fuel 239, 365372.

[103]. Sun, Y., Seetharaman, S., Zhang, Z. 2018. Integrating biomass pyrolysis with waste heat recovery from hot slags via extending the C-loops: Product yields and roles of slags. Energy 149, 792-803.

[104]. Susastriawan, A.A.P., Saptoadi, H., Purnomo. 2017. Small-scale downdraft gasifiers for biomass gasification: A review. Renew. Sustain. Energy Rev. 76, 989-1003.

[105]. T. Reed, T.B.R.a.A.D., A. Das. 1988. Handbook of Biomass Downdraft Gasifier Engine Systems. The Biomass Energy Foundation Press.

[106]. Tendall, D.M., Binder, C.R. 2011. Nuclear Energy in Europe: Uranium Flow Modeling and Fuel Cycle Scenario Trade-Offs from a Sustainability Perspective. Environ. Sci. Technol. 45(6), 2442-2449.

[107]. Thakur, V.K., Singha, A.S., Thakur, M.K. 2012. Modification of Natural Biomass by Graft Copolymerization. Int. J. Polym. Anal. Ch. 17(7), 547-555.

[108]. Tinaut, F.V., Melgar, A., Pérez, J.F., Horrillo, A. 2008. Effect of biomass particle size and air superficial velocity on the gasification process in a downdraft fixed bed gasifier. An experimental and modelling study. Fuel Process Technol. 89(11), 10761089. 
[109]. Waheed, Q.M.K., Wu, C., Williams, P.T. 2016. Hydrogen production from high temperature steam catalytic gasification of bio-char. J. Energy Inst. 89(2), 222-230.

[110]. Wang, R., Huang, Q., Lu, P., Li, W., Wang, S., Chi, Y., Yan, J. 2015a. Experimental study on air/steam gasification of leather scraps using U-type catalytic gasification for producing hydrogen-enriched syngas. Int. J. Hydrogen Energy 40(26), 8322-8329.

[111]. Wang, S., Dai, G., Yang, H., Luo, Z. 2017a. Lignocellulosic biomass pyrolysis mechanism: A state-of-the-art review. Prog. Energy Combust. Sci. 62, 33-86.

[112]. Wang, X., Xu, T., Jin, X., Hu, Z., Liu, S., Xiao, B., Chen, Z., Hu, M. 2017b. CuO supported on olivine as an oxygen carrier in chemical looping processes with pine sawdust used as fuel. Chem. Eng. J. 330, 480-490.

[113]. Wang, Y., Kinoshita, C.M. 1993. Kinetic model of biomass gasification. Solar Energy 51(1), 19-25.

[114]. Wang, Z.-t., Huang, W.-g., Zhang, P., Xin, L. 2011. A contrast study on different gasifying agents of underground coal gasification at Huating Coal Mine. J. Coal Sci. Eng. (China) 17(2), 181.

[115]. Wang, Z., He, T., Qin, J., Wu, J., Li, J., Zi, Z., Liu, G., Wu, J., Sun, L. 2015b. Gasification of biomass with oxygen-enriched air in a pilot scale two-stage gasifier. Fuel 150, 386393.

[116]. Wei, J., Guo, Q., Ding, L., Yoshikawa, K., Yu, G. 2017. Synergy mechanism analysis of petroleum coke and municipal solid waste (MSW)-derived hydrochar co-gasification. Appl. Energy 206, 1354-1363.

[117]. Wei, L., Yang, H., Li, B., Wei, X., Chen, L., Shao, J., Chen, H. 2014. Absorption-enhanced steam gasification of biomass for hydrogen production: Effect of calcium oxide 
addition on steam gasification of pyrolytic volatiles. Int. J. Hydrogen Energy 39(28), 15416-15423.

[118]. Wieckert, C., Obrist, A., von Zedtwitz, P., Maag, G., Steinfeld, A. 2013. Syngas Production by Thermochemical Gasification of Carbonaceous Waste Materials in a 150 kWth Packed-Bed Solar Reactor. Energy Fuels 27(8) 4770-4776.

[119]. Xiao, R., Chen, X., Wang, F., Yu, G. 2010a. Pyrolysis pretreatment of biomass for entrained-flow gasification. Appl. Energy 87(1), 149-155.

[120]. Xiao, X., Le, D.D., Li, L., Meng, X., Cao, J., Morishita, K., Takarada, T. 2010b. Catalytic steam gasification of biomass in fluidized bed at low temperature: Conversion from livestock manure compost to hydrogen-rich syngas. Biomass Bioenergy 34(10), 15051512.

[121]. Yadav, D., Banerjee, R. 2016. A review of solar thermochemical processes. Renew Sustain. Energy Rev. 54, 497-532.

[122]. Yamazaki, T., Kozu, H., Yamagata, S., Murao, N., Ohta, S., Shiya, S., Ohba, T. 2005. Effect of Superficial Velocity on Tar from Downdraft Gasification of Biomass. Energy Fuels 19(3), 1186-1191.

[123]. Yan, L., Cao, Y., Zhou, H., He, B. 2018. Investigation on biomass steam gasification in a dual fluidized bed reactor with the granular kinetic theory. Bioresour. Technol. 269, 384-392.

[124]. Z'Graggen, A., Haueter, P., Trommer, D., Romero, M., de Jesus, J.C., Steinfeld, A. 2006. Hydrogen production by steam-gasification of petroleum coke using concentrated solar power-II Reactor design, testing, and modeling. Int. J. Hydrogen Energy 31(6), 797-811. 
[125]. Zhang, J., Xu, C., Song, Z., Huang, Y., Wu, Y. 2019a. Decision framework for ocean thermal energy plant site selection from a sustainability perspective: The case of China. J. Clean. Prod. 225, 771-784.

[126]. Zhang, Y., Xu, P., Liang, S., Liu, B., Shuai, Y., Li, B. 2019b. Exergy analysis of hydrogen production from steam gasification of biomass: A review. Int. J. Hydrogen Energy. 44(28) 14290-14302. 
Table 1: Merits and demerits of the different gasification processes.

\begin{tabular}{|c|c|c|}
\hline Updraft gasifier & Downdraft gasifier & Cross draft gasifier \\
\hline
\end{tabular}


Table 2: Hydrogen generation as of steam gasification from various biomasses. Reprinted with permission from Ref. (Zhang et al., 2019b). Copyright 2019 Elsevier.

\begin{tabular}{|l|l|l|l|}
\hline Biomass & $\mathbf{H}_{2}(\mathbf{m o l} / \mathbf{k g})$ & $\begin{array}{l}\text { Exergy } \\
\text { effectiveness }(\boldsymbol{\%})\end{array}$ & Circumstances \\
\hline Rice shell & 6.56 & 10.28 & $650^{\circ} \mathrm{C}, \mathrm{CaO} / \mathrm{C}=1$ \\
\hline Cotton stalk & 8.26 & 11.31 & $650^{\circ} \mathrm{C}, \mathrm{CaO} / \mathrm{C}=1$ \\
\hline Sawdust & 9.02 & 11.69 & $650^{\circ} \mathrm{C}, \mathrm{CaO} / \mathrm{C}=1$ \\
\hline Corn stalk & 8.79 & 12.81 & $650^{\circ} \mathrm{C}, \mathrm{CaO} / \mathrm{C}=1$ \\
\hline Wheat straw & 8.53 & 12.98 & $650^{\circ} \mathrm{C}, \mathrm{CaO} / \mathrm{C}=1$ \\
\hline Food waste & 32.20 & 26.12 & $900^{\circ} \mathrm{C}, \mathrm{S} / \mathrm{B}=0.2$ \\
\hline Pine sawdust & 28.55 & 32.03 & $900^{\circ} \mathrm{C}, \mathrm{S} / \mathrm{B}=0.2$ \\
\hline Wood residue & 27.86 & 32.92 & $900^{\circ} \mathrm{C}, \mathrm{S} / \mathrm{B}=0.2$ \\
\hline Wood chip & 28.30 & 33.37 & $900^{\circ} \mathrm{C}, \mathrm{S} / \mathrm{B}=0.2$ \\
\hline Green wastes & 30.32 & & $900^{\circ} \mathrm{C}, \mathrm{S} / \mathrm{B}=0.2$ \\
\hline Coffee bean husk & 34.32 & & \\
\hline Municipal & 32.94 & & \\
\hline & & & \\
\hline
\end{tabular}


Table 3: Reveals the hydrogen generation by steam gasification of various biomasses on several S/B proportions.

\begin{tabular}{|c|c|c|c|}
\hline Type of biomass & $\mathrm{S} / \mathrm{B}$ ratio & $\mathrm{H}_{2}$ yield (mol/kg) & References \\
\hline Wood pellets & $0.24-0.38$ & 27.5 & $\begin{array}{l}\text { (Campoy et al., } \\
2009)\end{array}$ \\
\hline Municipal solid waste & 0.77 & 38.60 & (He et al., 2009) \\
\hline Pine sawdust & 2.70 & 39.40 & (Lv et al., 2003) \\
\hline Pinewood blocks & $0.32-0.69$ & 44.13 & (Lv et al., 2007) \\
\hline Palm oil waste & $1.33-2.67$ & $66.63-58.07$ & (Li et al., 2009b) \\
\hline Rice husk & $1.5-2.5$ & $15.77-13.41$ & (Li et al., 2010) \\
\hline Pine sawdust & $1.43-2.8$ & $55.91-29.11$ & (Luo et al., 2009b) \\
\hline Palm kernel shell & $1.5-2.5$ & $14.35-48.97$ & (Khan et al., 2014) \\
\hline Coconut shell & $1.69-3.10$ & $38.65-42.10$ & $\begin{array}{l}\text { (Alipour } \\
\text { Moghadam et al., } \\
\text { 2014) }\end{array}$ \\
\hline White fir & $0.83-1.58$ & $10.28-8.68$ & $\begin{array}{l}\text { (Acharya et al., } \\
2010)\end{array}$ \\
\hline Sewage sludge & $1.5-2.0$ & $15.07-14.41$ & (Gai et al., 2016) \\
\hline Municipal solid waste & $1.23-3.08$ & $40.34-32.05$ & $\begin{array}{l}\text { (Nipattummakul et } \\
\text { al., 2010) }\end{array}$ \\
\hline Wood residue & $0.5-1.0$ & $19.06-25.40$ & $\begin{array}{l}\text { (Fremaux et al., } \\
2015)\end{array}$ \\
\hline
\end{tabular}


Table 4: Hydrogen generation by the steam gasification of biomass on diverse steam flow rates.

\begin{tabular}{|l|l|l|l|}
\hline Type of biomass & Steam flow rate (g/min) & $\mathbf{H}_{2}$ yield (mol/kg) & References \\
\hline Pine wooden blocks & $0.072-0.27$ & 44.13 & (Lv et al., 2007) \\
\hline Pine sawdust & 1.2 & 39.40 & (Lv et al., 2003) \\
\hline Wood pellets & $0-0.43$ & 27.5 & $\begin{array}{l}\text { (Campoy et al., } \\
\text { 2009) }\end{array}$ \\
\hline Beechwood & 0.16 & 22.03 & $\begin{array}{l}\text { (Chuayboon et } \\
\text { al., 2018) }\end{array}$ \\
\hline Cornstalk & 0.50 & 24.49 & $\begin{array}{l}\text { (Wei et al., } \\
\text { 2014) }\end{array}$ \\
\hline Wood pellet & 0.05 & 6.57 & $\begin{array}{l}\text { (Wi et al., 2014) } \\
\text { 2016) }\end{array}$ \\
\hline & 0.1 & 4.78 & 27.74 \\
\hline
\end{tabular}


2019-11-26

\section{Energy production from steam}

gasification processes and parameters

that contemplate in biomass gasifier - a review

Siwal, Samarjeet Singh

Elsevier

Siwal SS, Zhang Q, Sun C, et al., (2020) Energy production from steam gasification processes and parameters that contemplate in biomass gasifier - a review. Bioresource Technology, Volume 297, February 2020, Article number 122481

https://doi.org/10.1016/j.biortech.2019.122481

Downloaded from Cranfield Library Services E-Repository 